Loyalitas Kreativitas

Aldi Masyarakat Kreatif
P-ISSN 2722-2101, E-ISSN 2722-4201

Program Studi Ekonomi Manajemen Universitas Pamulang

Jurnal LOKABMAS Kreatif Vol.02,No.02.Juli 2021 Hal.98-106

Email:jurnalkreatif.manajemen@gmail.com

\title{
PENYULUHAN STRATEGI PEMASARAN DAN PRAKTEK PEMBUATAN KERIPIK KULIT PISANG DI RT.003 RW.08 KELURAHAN SERPONG, KECAMATAN SERPONG, KOTA TANGERANG SELATAN
}

\author{
Nurselvi, Ade Irawan, Aceng Abdul Hamid, Laily Maknin Zubaedah \\ Dosen Program Studi Teknik Industri, Fakultas Teknik, Universitas Pamulang, \\ dosen02045@unpam.ac.id, dosen00958@unpam.ac.id, \\ dosen00651@unpam.ac.id, dosen01235@unpam.ac.id
}

\begin{abstract}
ABSTRAK
Kegiatan Pengabdian Masyarakat (PKM) merupakan salah satu Tridharma Perguruan Tinggi yang wajib dilakukan oleh setiap dosen di Universitas Pamulang. Kegiatan PKM bertujuan membantu masyarakat sekitar kampus dengan menerapkan bidang keilmuan dosen. PKM 2020/2021 tim PKM Prodi Teknik Industri Universitas Pamulang mengadakan pengabdian di RT.003RW.08 Kelurahan Serpong, Kecamatan Serpong, Kota Tangerang Selatan. Sejak masa pandemik masyarakat masih kesulitan untuk dapat kembali hidup normal yang dipengaruhi oleh pendapatan yang belum stabil. Kegiatan PKM bertujuan untuk membantu warga RT.003/RW.08 dalam berinovasi dengan cara menggali potensi yang ada guna mensejahterakan kehidupan keluarga pada khususnya dan masyarakat pada umumnya. Secara khusus tujuan kegiatan PKM(1) Membangkitkan jiwa wirausaha warga dengan cara selalu berinovasi untuk memberi nilai tambah bahan yang seringkali terlupakan (kulit pisang) yang banyak terdapat di lingkungannya. (2) Menambah keterampilan warga RT.003/RW.08 cara membuat produk keripik kulit pisang. (3) Memberikan pemahaman strategi pemasaran yang sesuai dengan masa sekarang ini. Kegiatan PKM ini dilakukan dengan peninjauan lokasi rencana PKM dan mengetahui permasalahan yang ada di lokasi tersebut dengan cara brainstorming antara dosen dan beberapa pemuka masyarakat. Kemudian TIM PKM menawarkan solusi dari permasalahan yang ada dan disetujui maka dilakukanlah kegiatan PKM ini. Kegiatan PKM berjalan dengan baik dimana peserta yang kebanyakan ibu rumah tangga sangat antusias dalam mengikuti kegiatan ini.
\end{abstract}

Kata Kunci : Keripik, Kulit Pisang, Pemasaran.

\section{A. Pendahuluan}

Kota Tangerang Selatan (Tangsel) terdiri dari 7 kecamatan dan 54 kelurahan, dan 3844 Rukun Tetangga, serta 735 Rukun Warga (RW). Kecamatan Serpong terdapat 9 Kelurahan, 486 RT, dan 112 RW. RT.003/RW.08 merupakan Rukun Tetangga yang terdapat di Kelurahan Serpong dengan Ketua RT Bapak Mulyadi. Daerah ini terletak tepat di belakang Pasar Serpong, Puskesmas Serpong dan Stasiun Serpong sehingga membuat RT.003/RW.08 menjadi wilayah yang ramai dan padat penduduk. Masyarakat yang tinggal dikawasan ini kebanyakan perantau dari daerah jawa barat dan sekitarnya. Mereka merantau ke serpong untuk mengadu nasib yang lebih baik. Kebanyakan masyarakatnya sudah berkeluarga dan sudah menetap cukup lama disini. Mayoritas mata pencarian warga RT.003/RW.08 pedagang dan kuli harian di Pasar Serpong. 
Loyalitas Kreativitas

Aldi Masyarakat Kreatil
P-ISSN 2722-2101, E-ISSN 2722-4201

Program Studi Ekonomi Manajemen Universitas Pamulang

Jurnal LOKABMAS Kreatif Vol.02,No.02.Juli 2021 Hal.98-106

Email:jurnalkreatif.manajemen@gmail.com
Sejak masa pandemik masyarakat masih kesulitan untuk dapat kembali hidup normal yang dipengaruhi oleh pendapatan yang belum stabil. Hal ini disebabkan kurangnya daya beli masyarakat dipasar, turunnya jumlah pengunjung pasar dan sedikitnya masyarakat yang naik ojek. Apabila dibiarkan berlarutlarut situasi ini akan membuat banyak hal yang terjadi dan berdampak kurang baik nantinya.

Untuk mendorong terjadinya proses transformasi sosial di masyarakat, dari kondisi masyarakat yang tidak berdaya menjadi berdaya, mandiri dan pada akhirnya menuju madani terutama diperkotaan perlu adanya intervensi khusus yakni dilakukan melalui proses saling belajar bukan hanya untuk meningkatkan pengetahuan dan keterampilan akan tetapi juga agar bisa berbagi nilai-nilai positif. Dengan beberapa pertimbangan yang ada maka kami Dosen Program Studi Teknik Industri memilih melakukan kegiatan Pengabdian Kepada Masyarakat (PKM) di wilayah ini kembali.

Kulit pisang merupakan hasil samping buah pisang yang jarang digunakan, biasanya hanya dibuang atau dijadikan pakan ternak. Kulit pisang dapat dijadikan makanan ringan seperti keripik yang enak dan lezat. Walaupun kulit pisang merupakan hasil samping namun memiliki kandungan gizi yang cukup banyak yaitu mengandung serat yang tinggi, vitamin $C$, Vitamin B, Kalsium, protein dan Karbohidrat.

Keripik kulit pisang merupakan makanan cemilan yang masih sedikit dijumpai dipasaran dan hanya kalangan tertentu saja yang mengetahui produk ini. Menurut emaga et.al dalam Aryani, et al (2018) bahwa kulit pisang

\section{B. Rumusan Masalah}

Berdasarkan latar belakang diatas dapat dirumuskan masalah : mengandung serat pangan dalam jumlah $50 \mathrm{~g} / 100 \mathrm{~g}$, sehingga merupakan serat pangan potensial bagi tubuh dan mampu memperlancar system metabolisme tubuh.

Pembuatan keripik kulit pisang diawali dengan pengumpulan kulit pisang, penyortiran bahan baku perlu diperhatikan bahwa kulit pisang tidak boleh lebih dari 4 jam diruang terbuka karena akan mempegaruhi warna kulit pisang menjadi hitam, lakukan perebutas agar kulit tidak menjadi hitam dan empuk serta membutuh mikroorganisme pada kulit pisang serta menghilangkan getah.

Kesadaran untuk pentingnya berwirausaha harus ditingkatkan dan didukung karena dapat mendukung bahkan menopang perekonomian keluarga pada khususnya dan meningkatkan kesejahteraan masyarakat pada umumnya. Serta masyarakat dituntut dapat berinovasi untuk memenuhi kebutuhan gizi keluarga tanpa memberatkan pengeluaran keluarga. Kegiatan ini bertujuan agar setiap keluarga dapat secara mandiri mencukupi kebuuhan hidupnya dengan cara berwirausaha.

Setelah di buat produk kerupuk kulit pisang maka tantangan selanjutnya adalah bagaimana cara memasarkannya, untuk itu dalam kegiatan PKM ini juga di sisipkan pengetahuan tentang strategi memasarkan produk makanan ringan secara online agar menarik minat pembeli. Dalam kegiatan ini masyarakat tidak hanya diajarkan membuat produk tapi juga bagaimana cara memasarkan produk. Dengan adanya kegiatan PKM ini diharapkan dapat membantu warga RT.003RW.08 Kelurahan Serpong dalam menggali potensi yang ada dan membantu perekonomian masyaratknya.

1. Apakah Kegiatan PKM ini dapat Membangkitkan jiwa wirausaha warga dengan cara selalu berinovasi untuk

2. memberi nilai tambah bahan yang seringkali terlupakan? 
3. Apakah Kegiatan PKM membuat produk keripik kulit pisang ini dapat menambah keterampilan warga RT.003/RW.08 ?

4. Apakah Kegiatan PKM ini dapat memberikan pemahaman strategi pemasaran yang sesuai dengan masa sekarang ini?

\section{Tujuan Kegiatan}

Tujuan umum kegiatan PKM membantu warga RT.003/RW.08 dalam berinovasi dengan cara menggali potensi yang ada guna mensejahterakan kehidupan keluarga pada khususnya dan masyarakat pada umumnya . Secara khusus tujuan kegiatan PKM adalah:

1. Membangkitkan jiwa wirausaha warga dengan cara selalu berinovasi untuk memberi nilai tambah bahan yang seringkali terlupakan (kulit pisang).

2. Menambah keterampilan warga RT.003/RW.08 cara membuat produk keripik kulit pisang.

3. Memberikan pemahaman strategi pemasaran yang sesuai dengan masa sekarang ini.

\section{F. Tinjauan Pustaka}

1. Strategi

Strategi adalah pendekatan secara keseluruhan yang berkaitan dengan gagasan, perencanaan, dan eksekusi, sebuah aktivitas dalam kurun waktu tertentu. Di dalam strategi yang baik terdapat kordinasi tim kerja, memiliki tema mengidentifikasi faktor pendukungnya sesuai dengan prinsip-prinsip pelaksanaan gagasan secara rasional, efesiensi dalam pendanaan dan memiliki taktik untuk mencapai tujuan secara efektif.

Strategi menunjukkan arahan umum yang hendak ditempuh oleh organisasi untuk mencapai tujuannya. Strategi ini merupakan rencana besar dan rencana penting. Setiap organisasi untuk mencapai tujuannya.
D. Manfaat umum kegiatan PKM membantu warga RT.003/RW.08 dalam berinovasi dengan cara menggali potensi yang ada guna mensejahterakan kehidupan keluarga pada khususnya dan masyarakat pada umumnya. Secara khusus Manfaat kegiatan PKM adalah:

1. Membangkitkan jiwa wirausaha warga

2. Menambah keterampilan warga

3. Memberikan pemahaman strategi pemasaran

\section{E. Pemecahan Masalah}

Untuk memecahkan masalah dalam kondisi yang serba tidak stabil ini adalah warga dituntut untuk selalu belajar, berinovasi, mandiri dan mampu beradaptasi dengan keadaan serta lingkungan. Kegiatan penyuluhan dan pelatihan yang diberikan kepada beberapa perwakilan warga khususnya ibu-ibu dianggap tepat sebagai solusi permasalahan ini.

Untuk lebih detail dan jelas dapat dilihat pada

Strategi ini merupakan rencana besar dan rencana penting. Setiap organisasi yang dikelola secara baik memiliki strategi, walaupun tidak dinyatakan secara eksplisit.

\section{Pemasaran}

Pemasaran merupakan salah satu lini penting dalam bisnis, sebuah produk mulai diperkenalkan hingga didistribusikan hingga sampai ke tangan konsumen merupakan tugas dari bagian pemasaran. Banyak metode atau cara yang dapat digunkan untuk memasarkan barang atau jasa. Tim pemasaran harus jeli dalam menentukan metode apa yang sesuai untuk memasarkan produknya. Metode pemasaran yang sesuai mempengaruhi penerimaan produk atau jasa dipasaran. Seiring dengan perkembangan 
zaman yang sangat dinamis ini maka tim pemasar harus selalu merupak pola pemsaran agar dapat bersaing dipasar bebas dengan kompetitornya.

\section{Strategi Pemasaran}

Strategi pemasaran merupakan salah satu penentu lakunya produk dipasaran. Strategi pemasaran yang benar akan meark minat konsumen terhadap produk yang ada. Digital marketing atau pemasaran secara digital merupakan salah satu media pemasaran yang diminati saat ini (Pradiani, 2017) khususnya masa pandemic paling banyak dan berhasil digunakan untuk menjual produk. Menurut Pradiani (2017), masyarakat saat ini mulai meninggalkan pemasaran tradisional dan beralih ke pemasaran digital karena pemasaran digital komunikasi dan transaksi dapat dilakukan setiap waktu/real time dan dapat mengglobal dalam waktu yang singkat. Mudahnya penggunaan pemasaran digital ini dapat membantu pengusaha pemula atau UMKM untuk mengembangkan pasarnya.

\section{Kulit Pisang}

Kulit pisang merupakan salah satu bagian dari tanaman pisang yang selama ini keberadaannya terabaikan. Menurut Munadjim (1998), kulit pisang merupakan bahan buangan (limbah buah pisang) yang cukup banyak jumlahnya yaitu kira-kira $1 / 3$ dari buah pisang yang belum dikupas. Sedangkan menurut Zainuddin (2004), kulit pisang adalah produk dari limbah industri pangan yang dimanfaatkan untuk bahan pakan ternak. Komposisi kimia terbanyak kulit pisang, di samping air adalah karbohidrat sebesar 18,50\%. Karbohidrat ini dapat dimanfaatkan sebagai bahan baku untuk pembuatan alkohol yang berguna sebagai bahan bakar, bahan industri kimia bahan kecantikan dan kedokteran. Manfaat lain kulit pisang yaitu sebagai bahan baku minuman beralkohol (anggur) dan makanan ternak, seperti kambing, sapi, kelinci dan lain-lain. Hal ini disebabkan nilai gizi kulit pisang cukup baik.

\section{G. Metode Pelaksanaan}

Tahap-tahap yang dilakukan dalam kegiatan ini meliputi:

1. Survei awal Survei ke lokasi RT.003/RW.

2. Fiksasi Jadwal Penentuan waktu kegiatan.

3. Persiapan Materi Kegiatan Penyusunan bahan/materi kegiatan yang meliputi: slide powerpoint, handout, alat serta bahan pembuatan keripik kulit pisang.

4. Pelaksanaan

Pelaksanaan PKM ini meliputi :

a. Penyuluhan interaktif secara offline dan online melalui aplikasi zoom meeting kegiatannya yaitu sosialisasi (pemaparan materi). Dipandu oleh Dr. Aceng Abdul Hamid, S.T., M.M

b. Penyuluhan dan pelatihan cara pembuatan keripik kulit pisang. Materi mengenai "Pembuatan Keripik Kulit Pisang" oleh Nurselvi, S.T.P., M.Sc.

c. Koordinator peserta kegiatan secara offline dilakukan oleh Ade Irawan, S.T., M.M.

d. Koordinator peserta dalam kegiatan Tanya jawab oleh Laily Maknin Z, S.T., M.B.A.

\section{H. Hasil dan Pembahasan}

Kegiatan pengabdian kepada masyarakat ini dilakukan secara offline dan online melalui aplikasi zoom meeting dikarenakan dalam kondisi pandemi Covid 19. Kegiatan PKM ini dihadiri oleh 4 Dosen dan 3 Mahasiswa Program Studi Teknik Industri Universitas Pamulang serta 15 Peserta yang terdiri dari 
Ketua RW.08, Ketua RT.003 dan serta warga RT.003/RW.08 Kelurahan Serpong.

Kegiatan PKM diawali dengan pemaparan terkait kegiatan yang akan dilaksanakan.

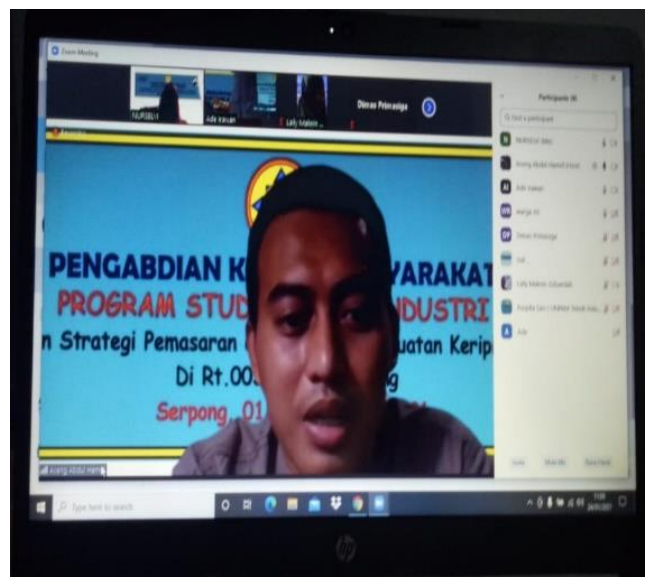

Gambar 2. Pembukaan kegiatan Pengabdian oleh Dr. Aceng Abdul Hamid, S.T.,.M.M

Pemaparan selanjutnya yaitu pembuatan keripik kulit pisang serta materi pemasaran yang akan disampaikan nantinya. Langkah pembutan

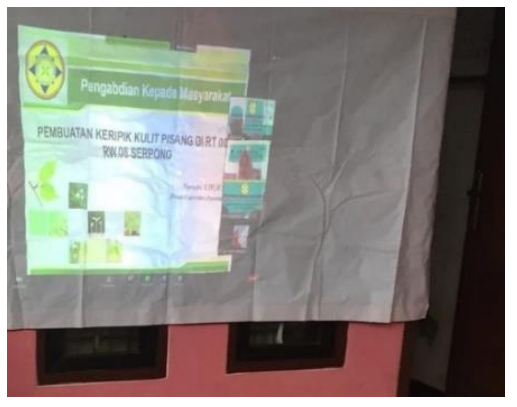

Gambar 3. Pemaparan cara pembuatan keripik kulit pisang oleh Nurselvi, S.T.P., M.Sc.
Kegiatan ini dibuka oleh Dr. Aceng Abdul Hamid, S.T., M.M. PKM merupakan bentuk pengabdian dosen kepada masyarakat sekitar khususnya sekitar kampus Universitas Pamulang.

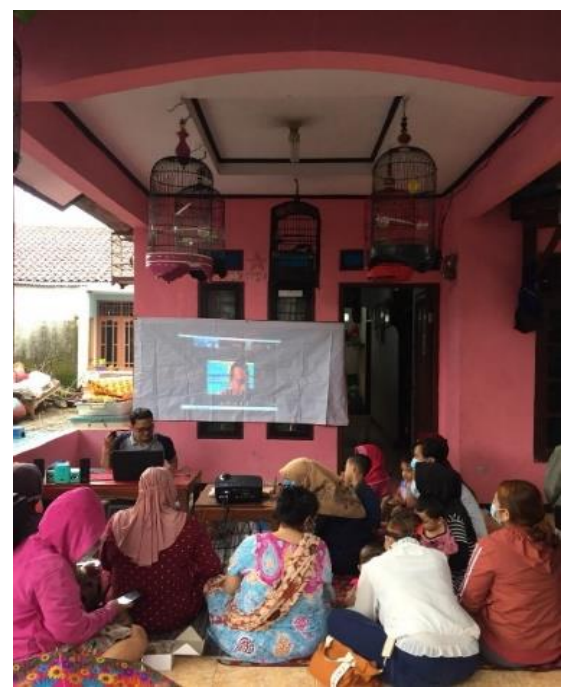

keripik kulit pisang disampaikan oleh Nurselvi, S.T.P.,M.Sc.

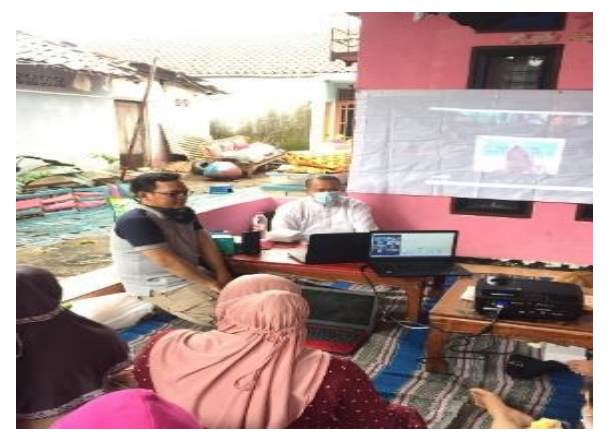

Gambar 3. Pemaparan cara pembuatan keripik kulit pisang oleh Nurselvi, S.T.P., M.Sc.

Langkah-langkah pembuatan Keripik Kulit pisang dapat di lihat pada Gambar 4 berikut ini. 


\section{Loyalitas Kreativitas}

Aldi Masyarakat Kreatif
P-ISSN 2722-2101, E-ISSN 2722-4201

Program Studi Ekonomi Manajemen Universitas Pamulang

Jurnal LOKABMAS Kreatif Vol.02,No.02.Juli 2021 Hal.98-106

Email:jurnalkreatif.manajemen@gmail.com
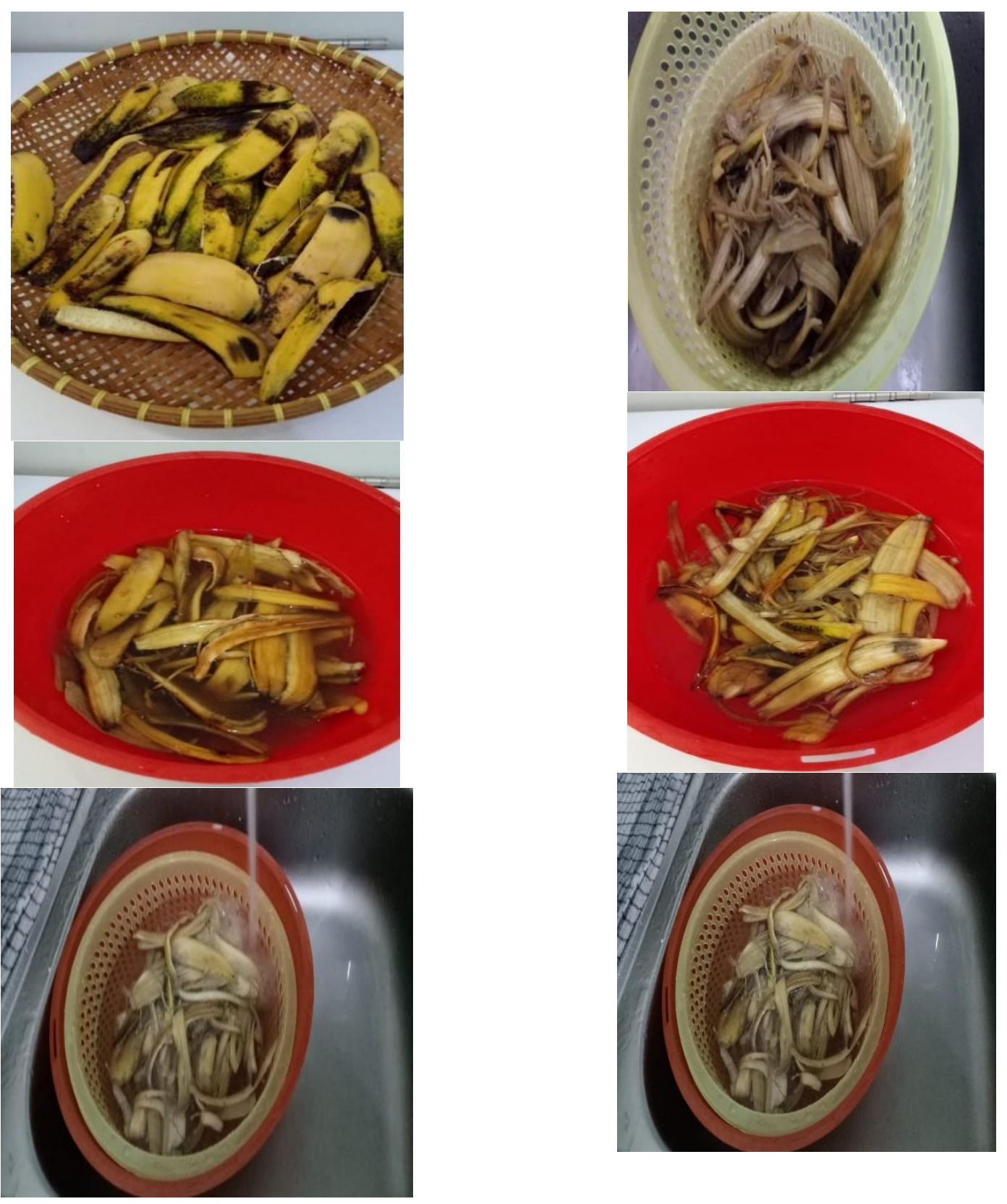


\section{Loyalitas Kreativitas}

Aldi Masyarakat Kreatif
P-ISSN 2722-2101, E-ISSN 2722-4201

Program Studi Ekonomi Manajemen Universitas Pamulang

Jurnal LOKABMAS Kreatif Vol.02,No.02.Juli 2021 Hal.98-106

Email:jurnalkreatif.manajemen@gmail.com
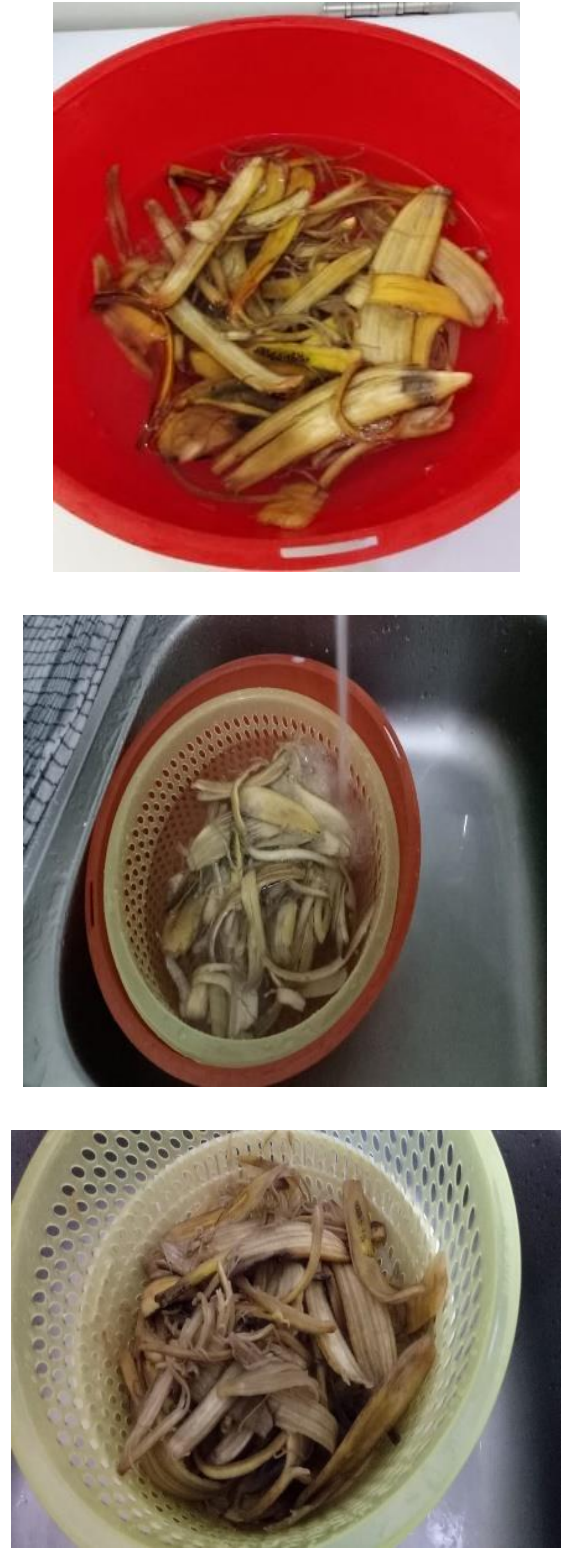
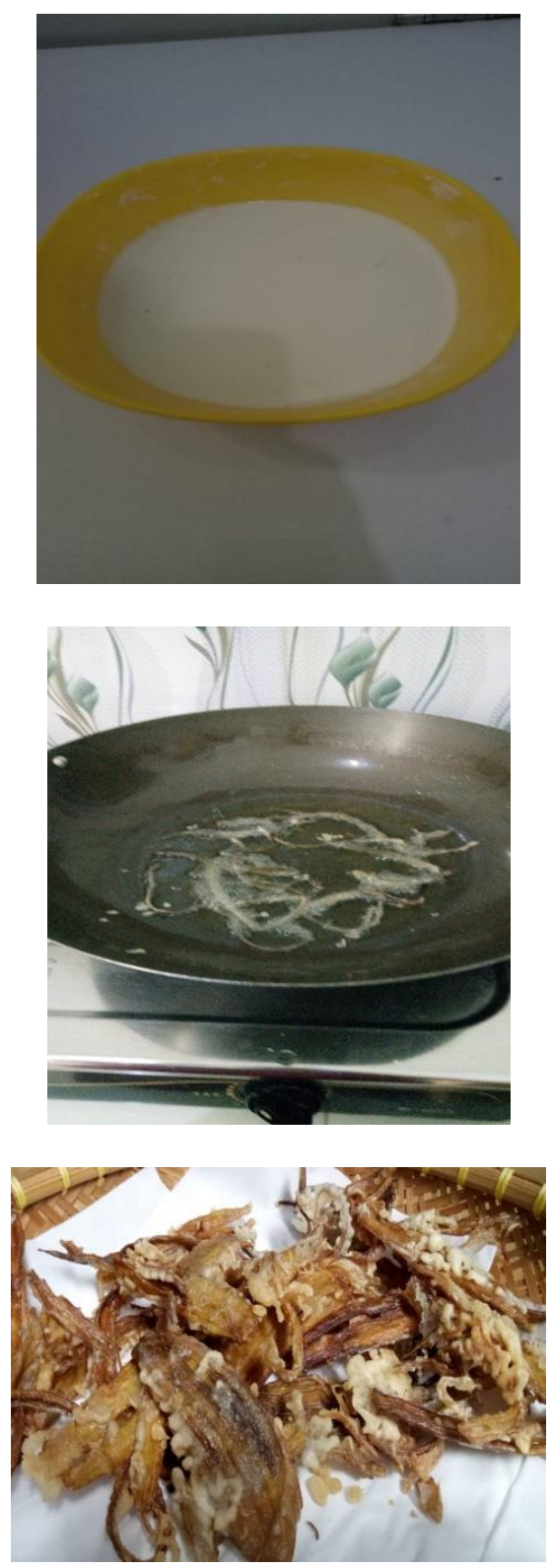


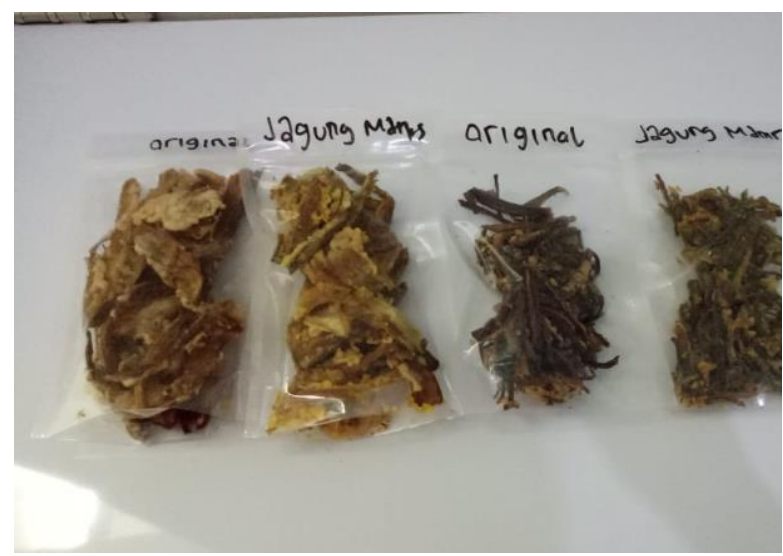

Gambar 4. (1) Kulit Pisang setelah dibersihkan dan disortir ; (2) Perendaman dengan Kapur sirih ; (3) pencucian dengan air; (4) Ditiriskan; (5) Perendaman dengan Garam; (6) Ditiriskan; (7) Pencucian dengan Air; (8) Perendaman dengan Gula (9) Ditiriskan; (10) Bahan Pencelup; (11) Digoreng hingga kekuningan; (12) Minyak Ditiriskan; (13) Keripik kulit pisang

Acara selanjutnya Tanya jawab dan menyerahan doorprise oleh Laily Maknin Zubaedah, S.T., M.B.A.

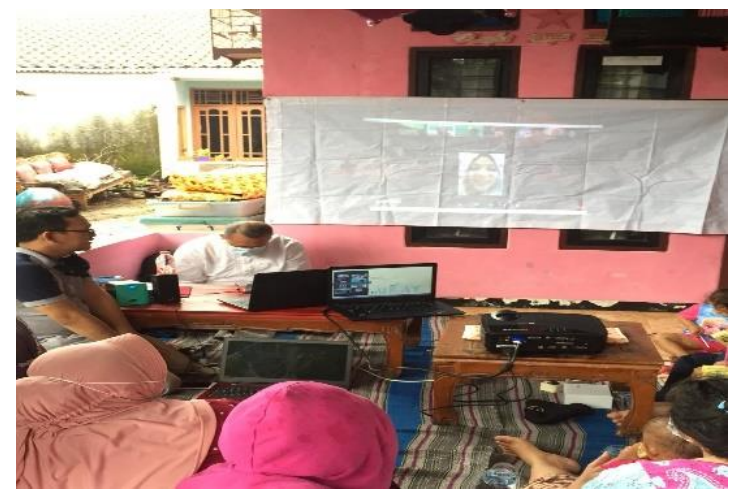

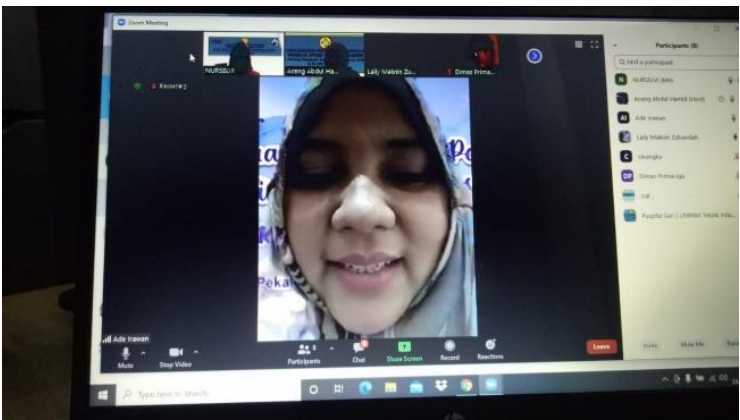

Gambar 5. Acara selanjutnya Tanya jawab oleh Laily Maknin Zubaedah, S.T., M.B.A. Kegiatan selanjutnya yaitu penyerahan kenang-kenangan keripik kulit pisang kepada Warga RT.003/RW.08, dimana dari Tim PKM di wakilkan oleh Ade Irawan, S.T., M.M.
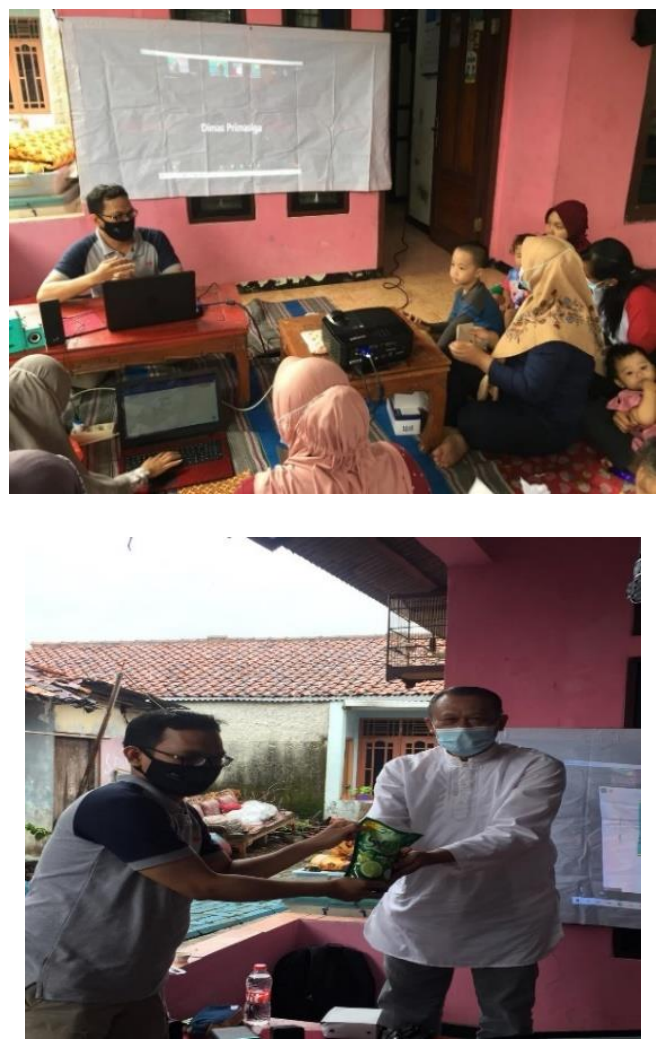

Gambar 6. penyerahan kenang-kenangan kepada Warga RT.003/RW.08, oleh Ade Irawan, S.T., M.M. 


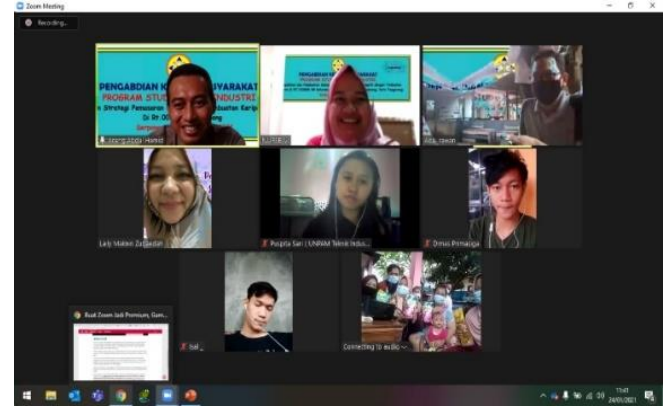

Gambar 7. Foto Bersama Online

\section{Kesimpulan}

Pelaksanaan kegiatan Pengabdian Kepada Masyarakat yang dilakukan oleh dosendosen Teknik Industri ini berjalan dengan lancar dan mendapat sambutan yang positif dari Warga RT.003/RW.08 serta kaderkader PKK dilingkungan RW.08. Dari kegiatan PKM ini dapat ditarik beberapa kesimpulan :

Amiruddin, Moh. Dkk. 2019. "Kepo Mbah Kupis" Kripik olahan dari limbah kulit pisang Camilan Beraneka rasa. Abdimas Berdaya : Jurnal Pengabdian Masyarakat Vol. 2 No. 2 (2019) PISSN:2685-1563.

Aryani, Titin. Dkk. 2018. Karakteristik Fisik, Kandungan Gizi Tepung Kulit Pisang dan Perbandingannya Terhadap Syarat Mutu Tepung Terigu. Jurnal Riset Sains dan Teknologi Vol 2 no.2 September 2018.

Handayani, Novi. Dkk. 2018. Pengaruh Influencer Marketing Sebagai strategi Pemasaran digital era Modern (Sebuah Strategi Literatur). Jurnal EKSEKUTIF Volume 15, no 1 Juni 2018.

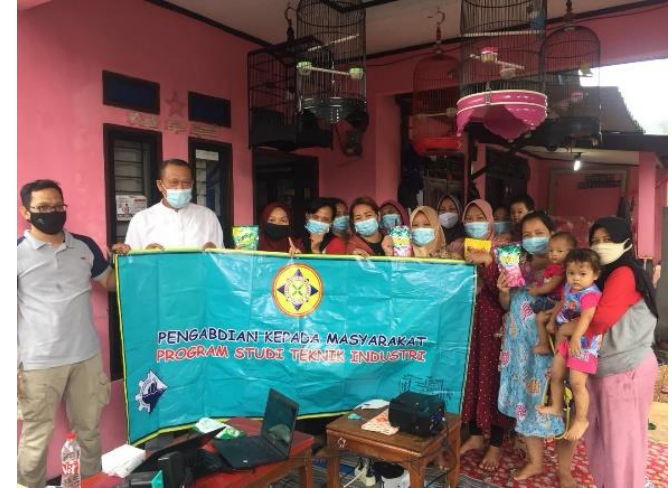

Gambar 8. Foto bersama Offline

1. Kegiatan PKM ini dapat membangkitkan jiwa wirausaha warga.

2. Kegiatan PKM ini menambah keterampilan warga RT.003/RW.08.

3. Kegiatan PKM ini memberikan pemahaman strategi pemasaran yang sesuai dengan masa sekarang ini.

\section{J. Daftar Pustaka}

Hartono, Arif. 2013. Pelatihan Pemanfaatan Limbah Kulit Pisang Sebagai Bahan Dasar pembuatan Kerupuk. Jurnal Inovasi dan Kewirausahaan Volume 2 No 3, September 2013, Hal 198- 203.

Oktavianita, Bella. Dkk. 2020. Pengembangan Ekonomi Desa Padanaan dengan Wirausaha Keripik Kulit pisang di Kabupaten Sumedang. Jurnal Pusat Inovasi Masyarakat ISSN 2721-897X: Juni 2020, Vol 2(4) 2020:690-695.

Pradiani, Theresia. 2017. Pengaruh Sistem Pemasaran Digital Marketing Terhadap Peningkatan Volume Penjualan Hasil Industri Rumahan. JIBEKA Volume 11 Nomor 2 Februari 2017 : 46-53.

Tim Universitas Pamulang. 2020. http://unpam.ac.id/visi-dan-misi 